\title{
An Investigation of the Relationship Between Organizational Ethical Climate and Positive Organizational Behaviors of the Staff at Shahrud University of Medical Sciences
}

\author{
ASHRAFI Zahra ${ }^{6}$, ASHRAFI Maliheh ${ }^{7}$, ASHRAFI Sakineh ${ }^{8}$, \\ ASHRAFI Aghabozorg'
}

\begin{abstract}
One of the problems that employees face today in organizations is ethical problems. Many organizations resort to unethical acts due to the intensified competition in achieving efficiency and profitability. This article has been conducted to examine the relationship between the ethical climate and positive organizational behavior at Shahrud University of Medical Sciences. To do this, 224 employees at Shahrud University of Medical Sciences were selected randomly. The research was done based on a survey. The examined questionnaires included standardized questionnaires of ethical climate and positive organizational behavior. SPSS-19 was used to analyze the data in this study. The reliability of the questionnaires was estimated using Cronbach's alpha. Thus, Cronbach's alpha was obtained 0.844 and 0.730 respectively for the ethical climate of the organization and positive organizational behaviors. The results showed that there is a positive and significant relationship between the ethical climate of the organization and positive organizational behaviors of the staff at Shahrud University of Medical Sciences.

Additionally, there are significant relationships among the instrumental ethical climate and the ethical climates of independence, caring, organizational rules and regulations, professional ethical rules and regulations and positive organizational behaviors among the staff at Shahrud University of Medical Sciences.
\end{abstract}

Keywords: organizational ethical climate, positive organizational behavior, Shahrud University of Medical Sciences

JEL: M12, M14

UDC: 378.6:61]:005.336(55)

005.31(55)

COBISS.SR-ID 265399820

Introduction

\footnotetext{
${ }^{6}$ Department of Management, Shahrood Branch, Islamic Azad University, Shahrood, Iran

${ }^{7}$ Department of Management, Shahrood Branch, Islamic Azad University, Shahrood, Iran

${ }^{8}$ Department of Management, Shahrood Branch, Islamic Azad University, Shahrood, Iran

${ }^{9}$ Department of Management, Shahrood Branch, Islamic Azad University, Shahrood, Iran
} 
Today, with more complexities in organizations and the prevalence of unethical and illegal tasks, the managers and leaders have begun to focus on creating and maintaining an ethical work environment for all organizations. An international research paper studied the employees of 4,000 businesses and found that $25 \%$ of employees believe that the ethical codes are disregarded in the organizational goals and about $17 \%$ also stated that the organization encourages unethical values among employees to achieve organizational goals (Wimbush, 1994). The ethical climate of the organization reflects the moral values and behavioral expectations and indicates the effect of morality on the decisions made by the members of the organization. This means that there are moral choices that the employees have to make and operationalize accordingly.

The ethical climate determines the extent to which decisions correspond to ethical criteria and how the employees approach ethical questions (Ozturk \& Bahcecik, 2003). The ethical climate is an important part of the organizational environment and culture and studies have shown that it not only affects the ethical dimension of the employees within the organization, but also affects the work efficiency (Victor, Parbotea \& Cullen, 2003). The ethical environment in healthcare environments (such as Shahrud University of Medical Sciences) includes the "specific circumstances of an organization that facilitates the discussion on the health problems of patients and resolving such circumstances provides a framework for ethical decision-making in clinical settings."

The ethical climate has been known as a mediating factor that can lead to the presence or absence or the increase and decrease in moral distress (Fogel, 2007; Schluter, Winch, Holzhauser and Henderson, 2008). The ethical climate is a type of work environment that reflects the guidelines and regulations and their connection with ethical outcomes (Martin Cullen, 2006). Some researchers believe that promoting ethics in working environments in healthcare organizations (such as Shahrud University of Medical Sciences) would lead to a better response on the part of employees against moral distress and other causes of discontent in workplace (Fogel, 2007; Schluter et al., 2008).

In recent decades, terms with a negative sense such as absenteeism and job dissatisfaction have appeared more frequently than positive words such as self-confidence, self-efficacy, hope, optimism, peace of mind, and emotional intelligence (the ability to identify and manage one's own emotions and those of the others). According to what is known, positive issues have been neglected in comparison with negatively oriented issues concerning organization and management. The application of positive psychology in the areas of organization and management has led to the creation of two new approaches in the field: positive organizational behavior focuses mainly on the micro aspects of organizational behavior and those positive aspects of human personality that can develop and grow.

- Positive organizational research focuses largely on the major aspects of organizational behavior and positive organizational behavior is thus affected by positive psychology.

- The recognition of positive organizational behavior and the development of positive thoughts increase the employee performance, efficiency, improved productivity, satisfaction and higher levels of socio-economic development and welfare.

Positive psychology does not focus solely on the individual level, but also emphasizes the organizational and social levels and capitalizes on social virtue, piety, responsibility, citizenship behavior, altruism, and morality.

Positive psychology observes the following characteristics over time:

1. Satisfaction with the past

2. Cheerfulness and happiness with the present

3. Hope and optimism for the future 


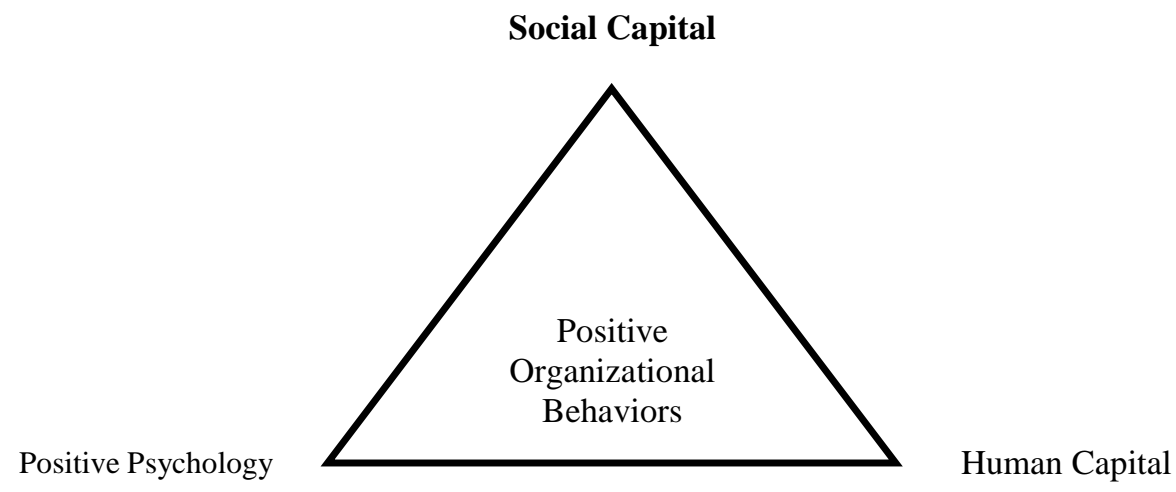

Fig. 1. The constituting factors of positive organizational behaviors

Luthans et al., (2004) believe that the optimal combination of positive psychology, human capital and social capital is an inevitable necessity to form a positive organizational behavior (Luthans et al., 2004; Luthans \& Joseph, 2004).

The constituent elements of positive organizational behavior can be seen below:

Creating hope, wishes, self-confidence, and self-esteem is different in Luthans's theory as it focuses on the study and evaluation of these positive features and is related to the work environment and organization. Luthans and Yusuf (2007) have proposed four basic dimensions of positive organizational behavior including:

1. Self-confidence

2. Hope

3. Optimism

4. Resilience

Since positive organizational behavior is the detection, recognition, and application of potential positive psychological human resources that can be measured and managed to improve organizational performance (Luthans, 2008), current managers should avoid engaging one's mind in human disadvantages and failures. Instead, they ought to focus on positive features and they have thus been able to develop and expand hope, self-efficacy, optimism, and self-confidence and improve individual and organizational performance. Now, given that social capital and human capital and positive psychology are inevitable in forming positive organizational behavior and, as they are a general basic step to advance organizational objectives and improve organizational performance, we use a main hypothesis and five subsidiary hypotheses to explain this subject at Shahrud University of Medical Sciences. With regard to the degree to which the staff have access to the ethical climate of the organization and its relationship with positive organizational behavior, we use the model developed Luthans and Yusuf. This model comprehensively includes all factors of corporate ethics throughout the organization to evaluate the organizational ethical climate and then discuss the correlation between these two variables. Therefore, in this study, we use the model developed by Victor and Cullen (1987 and 1988) to assess the ethical climate of the organization. The ethical climate types found in this theory are: A) the instrumental ethical climate, B) the ethical climate of caring, C) the ethical climate of independence, D) the ethical climate of organizational rules, and E) the ethical climate of professional rules. To examine positive organizational behavior, we use the model developed by Luthans and Yusuf (2007). This theory includes aspects of self-confidence, hope, optimism and resilience.

For many years, psychologists focused on the negative aspects of performance and human behavior and less attention was paid to the positive features. Recently, however, a movement 
has emerged in the field that focuses on the positive aspects of behavior in seeking the growth and development of individuals, organizations, and society and its main effects can be observed in academic and applied research (Simar Asl et al., 2010). The researchers are of the opinion that by relying on the theory of positive organizational behavior, the staff can realize their innermost potentials and organizational efficiency can be promoted through the efforts that are facilitated by capacities and abilities inherent to all human beings. Humans become aware of their potential powers and the abilities to realize their self-esteem through positive organizational behavior. The realization of such capabilities provides them with self-esteem and self-confidence and this in turn makes them more mature.

\section{Research hypotheses}

The main hypothesis

There is a significant relationship between the organizational ethical climate and positive organizational behaviors of the staff at Shahrud University of Medical Sciences.

Subsidiary hypotheses

- There is a significant relationship between the instrumental ethical climate and positive organizational behaviors of the staff at Shahrud University of Medical Sciences.

- There is a significant relationship between the ethical climate of independence and positive organizational behaviors of the staff at Shahrud University of Medical Sciences.

- There is a significant relationship between the ethical climate of caring and positive organizational behaviors of the staff at Shahrud University of Medical Sciences.

- There is a significant relationship between the ethical climate of rules and regulations and positive organizational behaviors of the staff at Shahrud University of Medical Sciences.

- There is a significant relationship between the ethical climate of professional rules and ethical codes and positive organizational behaviors of the staff at Shahrud University of Medical Sciences.

\section{Research Method}

In this study, the research method follows a descriptive and correlational design in terms of methodology and nature and it is considered applied research in terms of purpose. Applied research draws on the cognitive and informational contexts through fundamental research and is used to meet human needs and improve and optimize tools, objects, and models in line with the development of welfare and promotion in human life.

In terms of its design and research method, the current research is descriptive.

In such studies, the researchers approach the qualities and features of the issue and want to know the nature of the phenomenon, the variable, and the objective or subjective features.

\section{Statistical population}

Using Cochran's formula, the sample size in this study consisted of 224 participants. This sample has been randomly selected from the staff at Shahrud University of Medical Sciences. 


\section{Questionnaire}

In the present study, the standardized questionnaire of positive organizational behavior was used based on the model developed by Yusuf and Luthans (2007) to collect the data. Additionally, the standard questionnaire developed by Victor and Cullen (1988) was used to assess the organizational ethical climate and the dimensions and variables of the topic that is being investigated.

\section{Validity}

In this study, the content validity of the questionnaires was considered. In this approach, the questionnaire items were developed based on research hypotheses.

Then, these items were viewed and were finally corrected and verified by the supervising professor. Moreover, the validity of the questionnaires was determined by factor analysis. The results of the evaluation of ethical climate are provided below:

The results of Bartlett's test that approximates chi-square statistic are provided in Table 1. Bartlett's test Sig value is less than 5 percent (0.000), suggesting that the factor analysis is appropriate in identifying the operating structure model. In addition, since the amount of KMO is 0.789 , the sample size (i.e. the number of respondents) is sufficient. On the other hand, the variance is 59.115 percent.

Therefore, the validity of the results of the factor analysis is more than 59 percent for this survey.

Table 1. The results of factor analysis for the questionnaire of organizational ethical climate

\begin{tabular}{|l|l|l|}
\hline Variance percentage & Value Sig & Measure KMO \\
\hline 59.115 & 0.000 & 0.789 \\
\hline
\end{tabular}

The results of the test designed for the questionnaire of positive organizational behaviors are given below:

The results of Bartlett's test that approximates chi-square statistic are provided in Table 2. Bartlett's test Sig value is less than 5 percent (0.000), suggesting that the factor analysis is appropriate in identifying the operating structure model. In addition, since the amount of KMO is 0.764 , the sample size (i.e. the number of respondents) is sufficient. On the other hand, the variance is 54.599 percent.

Therefore, the validity of the results of the factor analysis is more than 54 percent for the survey.

Table 2. The results of factor analysis for the questionnaire of positive organizational behaviors

\begin{tabular}{|l|l|l|}
\hline Variance percentage & Value Sig & Measure KMO \\
\hline 54.599 & 0.000 & 0.764 \\
\hline
\end{tabular}

The results of this test for the questionnaire of positive organizational behaviors are given below:

\section{Questionnaire reliability}

To make sure of the reliability of the questionnaire distributed among the employees, the SPSS statistical software was used to calculate Cronbach's alpha coefficient for the questionnaire. This coefficient was calculated as 0.844 for the ethical climate questionnaire and 0.730 for the positive organizational behaviors.

Thus, it is concluded that the reliability of the questionnaire is acceptable. 
Table 3. The values of Cronbach's alpha for the questionnaires

\begin{tabular}{|l|l|l|l|}
\hline \multicolumn{2}{|l|}{ Organizational positive behaviors } & \multicolumn{2}{l|}{ Organizational ethical climate } \\
\hline Cronbach's alpha & Number of questions & Cronbach's alpha & Number of questions \\
\hline 0.730 & 12 & 0.844 & 26 \\
\hline
\end{tabular}

\section{Findings}

Descriptive statistics

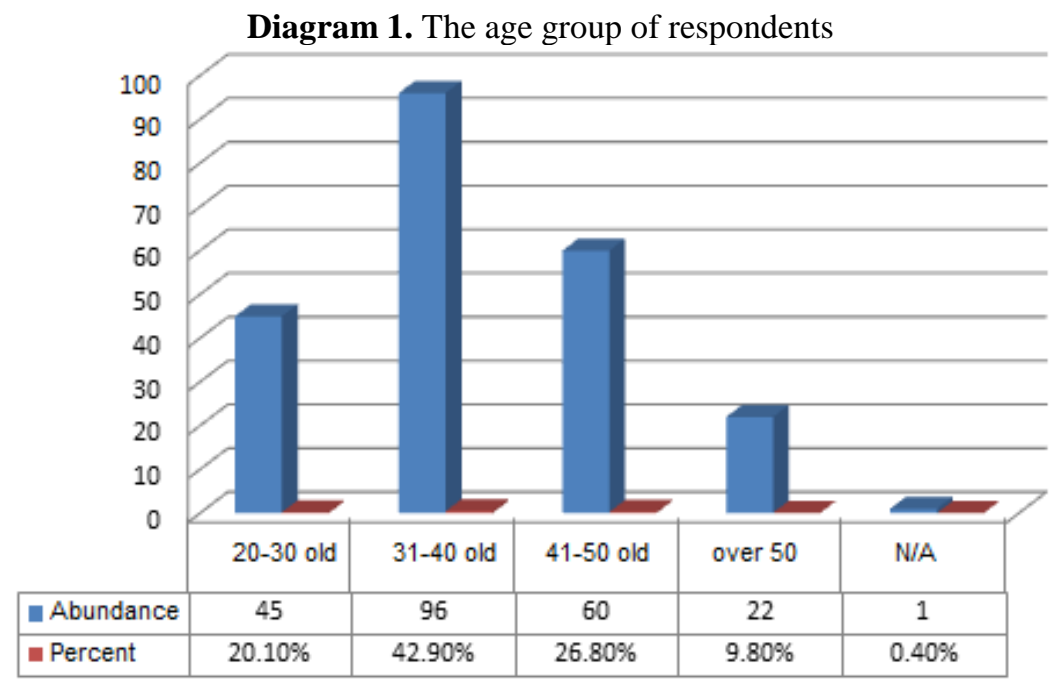

Diagram 2. The gender of respondents

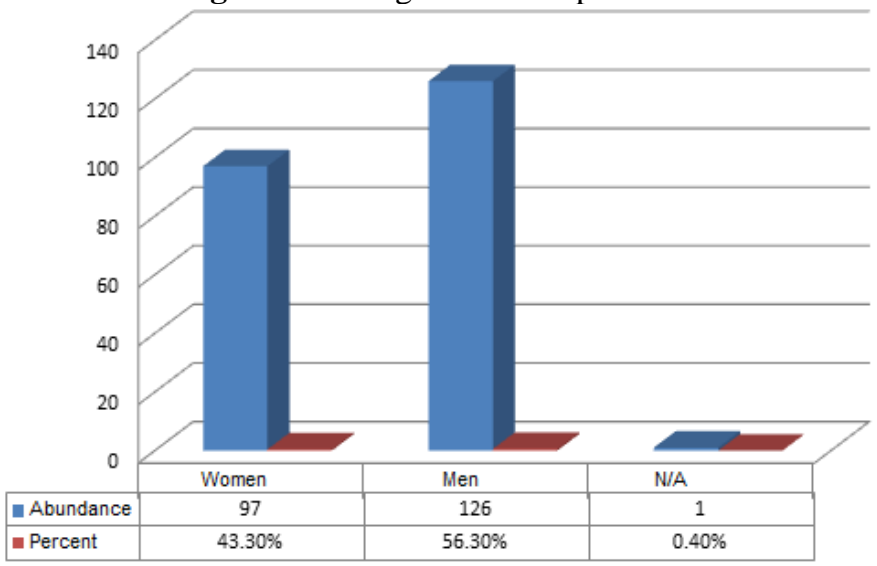


Diagram 3. The educational level of respondents

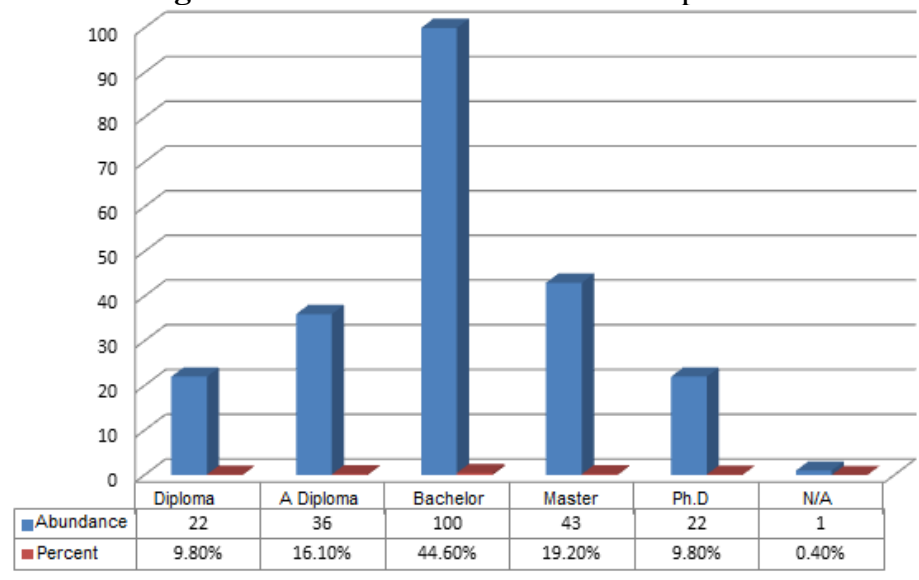

Diagram 4. The marital status of respondents

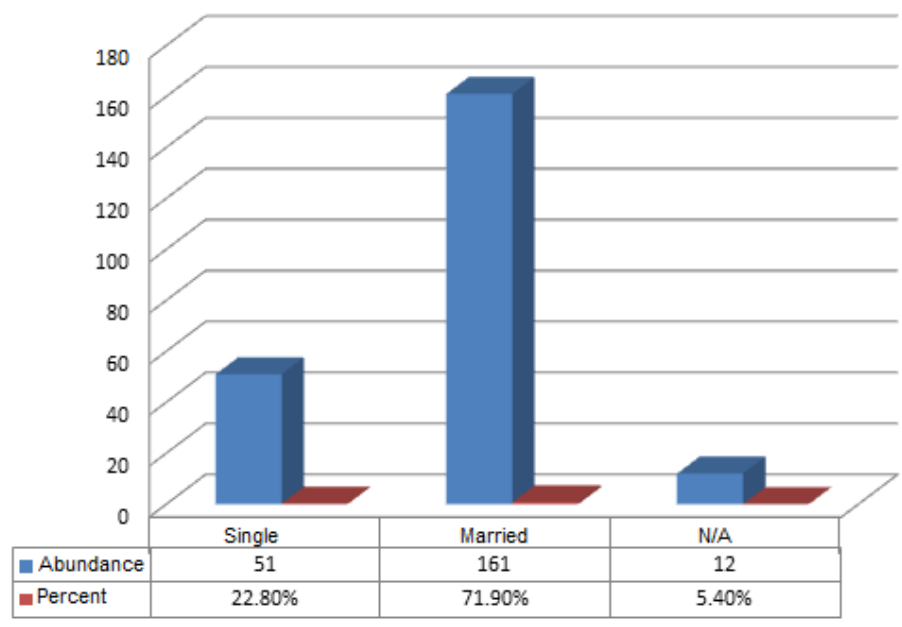

Diagram 5. The respondents' years of service

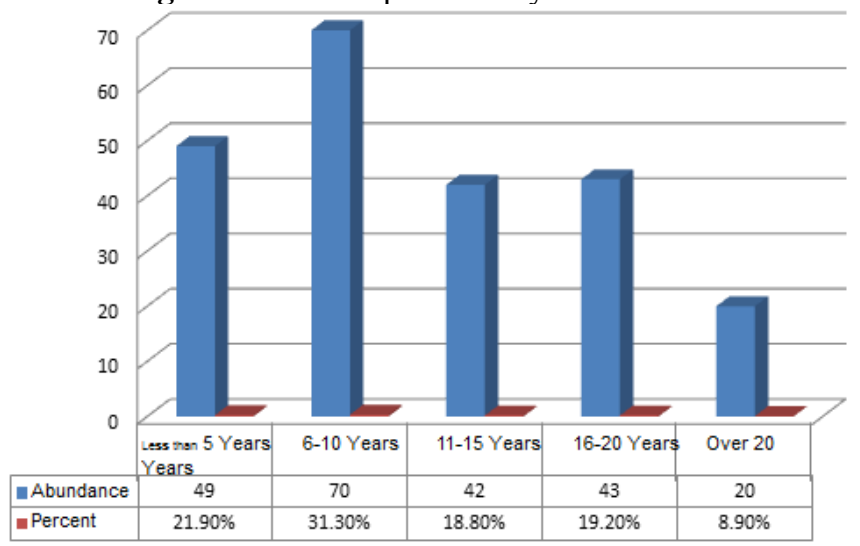

Inferential statistics 


\section{Kolmogorov-Smirnov test}

With respect to the components of the organizational ethical climate and organizational behaviors, the significance levels of the results of this test are given in Table 4. As can be seen, the positive organizational value is more than $5 \%$, therefore, the distribution is normal and the parametric test is used to examine the hypotheses.

Table 4. The results of Kolmogorov-Smirnov test

\begin{tabular}{|l|l|l|l|}
\hline \multicolumn{2}{|l|}{} & $\begin{array}{l}\text { Organizational ethical } \\
\text { climate }\end{array}$ & $\begin{array}{l}\text { Positive organizational } \\
\text { behavior }\end{array}$ \\
\hline Number of data & 224 & 224 \\
\hline $\begin{array}{l}\text { Normal } \\
\text { parameter }\end{array}$ & Mean & 2.98 & 3.04 \\
\hline \multirow{2}{*}{$\begin{array}{l}\text { The highest } \\
\text { deviation }\end{array}$} & SD & 0.418 & 0.419 \\
\cline { 2 - 4 } & Absolute & 0.084 & 0.079 \\
\hline value & Positive & 0.058 & 0.079 \\
\cline { 2 - 4 } $\begin{array}{l}\text { Z value of Kogative } \\
\text { Smirnov }\end{array}$ & -0.084 & -0.057 \\
\hline \multicolumn{2}{|l|}{ Sig value (interquartile) } & 1.253 & 1.182 \\
\hline
\end{tabular}

\section{The evaluation of the main hypothesis}

Table 5 shows the results of the test. This table includes the Pearson correlation coefficient, the significance level, and the number of data. According to this table, since the value of Sig (0.000) is less than 5 percent, the Pearson correlation coefficient is 0.617 for 224 data.

Therefore, the main research hypothesis is accepted and there is a significant relationship between the ethical climate and the positive organizational behaviors of the staff at Shahrud University of Medical Sciences. This coefficient is significant at the error level of $1 \%$ that is marked with **.

Table 5. The results of correlation test for the main hypothesis

\begin{tabular}{|l|l|l|l|}
\hline \multicolumn{2}{|c|}{} & $\begin{array}{l}\text { Organizational } \\
\text { ethical climate }\end{array}$ & $\begin{array}{l}\text { Positive } \\
\text { organizational } \\
\text { behaviors }\end{array}$ \\
\hline \multirow{4}{*}{$\begin{array}{l}\text { Organizational ethical } \\
\text { climate }\end{array}$} & $\begin{array}{l}\text { Pearson } \\
\text { correlation }\end{array}$ & 1 & $0.617^{\star \star}$ \\
\cline { 2 - 4 } & $\begin{array}{l}\text { Sig } \\
\text { (interquartile) }\end{array}$ & & 0.000 \\
\cline { 2 - 4 } & Number of data & 224 & 224 \\
\hline \multirow{3}{*}{$\begin{array}{l}\text { Positive } \\
\text { organizational } \\
\text { behaviors }\end{array}$} & $\begin{array}{l}\text { Pearson } \\
\text { correlation }\end{array}$ & $0.617^{\star \star}$ & 1 \\
\cline { 2 - 4 } & $\begin{array}{l}\text { Sig } \\
\text { (interquartile) }\end{array}$ & 0.000 & 224 \\
\cline { 2 - 4 } & Number of data & 224 & \\
\hline
\end{tabular}

\section{The evaluation of the first subsidiary hypothesis}

Table 6 shows the results of the test. The correlation coefficient is 0.564 for 223 data. 
Therefore, the first subsidiary hypothesis is accepted and there is a significant relationship between the instrumental ethical climate and the positive organizational behaviors of the staff at Shahrud University of Medical Sciences.

This coefficient is significant at the error level of $1 \%$ that is marked with **.

Table 6. The results of correlation test for the first subsidiary hypothesis

\begin{tabular}{|l|l|l|l|}
\hline \multicolumn{2}{|c|}{} & $\begin{array}{l}\text { Positive organizational } \\
\text { behaviors }\end{array}$ & $\begin{array}{l}\text { Instrumental ethical } \\
\text { climate }\end{array}$ \\
\hline \multirow{4}{*}{$\begin{array}{l}\text { Positive organizational } \\
\text { behaviors }\end{array}$} & $\begin{array}{l}\text { Pearson } \\
\text { correlation }\end{array}$ & 1 & $-0.564^{* *}$ \\
\cline { 2 - 4 } & $\begin{array}{l}\text { Sig } \\
\text { (interquartile) }\end{array}$ & & 0.000 \\
\cline { 2 - 4 } Number of data & 224 & 223 \\
\hline \multirow{4}{*}{$\begin{array}{l}\text { Instrumental ethical } \\
\text { climate }\end{array}$} & $\begin{array}{l}\text { Pearson } \\
\text { correlation }\end{array}$ & $-0.564^{* *}$ & 1 \\
\cline { 2 - 4 } & $\begin{array}{l}\text { Sig } \\
\text { (interquartile) }\end{array}$ & 0.000 & 223 \\
\cline { 2 - 4 } & Number of data & 223 & \\
\hline
\end{tabular}

\section{The evaluation of the second subsidiary hypothesis}

Table 7 shows the results of the test. The correlation coefficient is 0.581 for 223 data.

Therefore, the second subsidiary hypothesis is accepted and there is a significant relationship between the ethical climate of independence and positive organizational behaviors of the staff at Shahrud University of Medical Sciences.

This coefficient is significant at the error level of $1 \%$ and is marked with **.

Table 7. The results of correlation test for the second subsidiary hypothesis

\begin{tabular}{|c|c|c|c|}
\hline & & $\begin{array}{l}\text { Positive } \\
\text { organizational } \\
\text { behaviors }\end{array}$ & $\begin{array}{l}\text { The ethical climate of } \\
\text { independence }\end{array}$ \\
\hline \multirow{3}{*}{$\begin{array}{l}\text { Positive } \\
\text { organizational } \\
\text { behaviors }\end{array}$} & $\begin{array}{l}\text { Pearson } \\
\text { correlation }\end{array}$ & 1 & $0.581^{\star \star}$ \\
\hline & $\begin{array}{l}\text { Sig } \\
\text { (interquartile) }\end{array}$ & & 0.000 \\
\hline & Number of data & 224 & 223 \\
\hline \multirow{3}{*}{$\begin{array}{l}\text { The ethical climate of } \\
\text { independence }\end{array}$} & $\begin{array}{l}\text { Pearson } \\
\text { correlation }\end{array}$ & $0.581^{\star \star}$ & 1 \\
\hline & $\begin{array}{l}\text { Sig } \\
\text { (interquartile) }\end{array}$ & 0.000 & \\
\hline & Number of data & 223 & 223 \\
\hline
\end{tabular}

\section{The evaluation of the third subsidiary hypothesis}

Table 8 shows the results of the test. The correlation coefficient is 0.542 for 224 data.

Therefore, the third subsidiary hypothesis is accepted and there is a significant relationship between the ethical climate of caring and positive organizational behaviors of the staff at Shahrud University of Medical Sciences.

This coefficient is significant at the error level of $1 \%$ and is marked with **. 
Table 8. The results of correlation test for the third subsidiary hypothesis

\begin{tabular}{|l|l|l|l|}
\hline \multicolumn{2}{|c|}{} & $\begin{array}{l}\text { Positive organizational } \\
\text { behaviors }\end{array}$ & $\begin{array}{l}\text { The ethical } \\
\text { climate of caring }\end{array}$ \\
\hline \multirow{4}{*}{$\begin{array}{l}\text { Positive organizational } \\
\text { behaviors }\end{array}$} & $\begin{array}{l}\text { Pearson } \\
\text { correlation }\end{array}$ & 1 & $0.542^{\star \star}$ \\
\cline { 2 - 4 } & $\begin{array}{l}\text { Sig } \\
\text { (interquartile) }\end{array}$ & & 0.000 \\
\cline { 2 - 4 } $\begin{array}{l}\text { The ethical climate of } \\
\text { caring }\end{array}$ & $\begin{array}{l}\text { Pearson of data } \\
\text { correlation }\end{array}$ & 224 & 224 \\
\cline { 2 - 4 } & $\begin{array}{l}\text { Sig } \\
\text { interquartile) }\end{array}$ & $0.542^{\star \star}$ & 1 \\
\cline { 2 - 4 } & Number of data & 224 & 224 \\
\hline
\end{tabular}

\section{The evaluation of the fourth subsidiary hypothesis}

Table 9 shows the results of the test. The correlation coefficient is 0.536 for 223 data.

Therefore, the fourth subsidiary hypothesis is accepted and there is a significant relationship between the ethical climate of organizational rules and regulations and positive organizational behaviors of the staff at Shahrud University of Medical Sciences. This coefficient is significant at the error level of $1 \%$ and is marked with $* *$.

Table 9. The results of correlation test for the fourth subsidiary hypothesis

\begin{tabular}{|l|l|l|l|}
\hline \multicolumn{2}{|c|}{} & $\begin{array}{l}\text { Positive } \\
\text { organizational } \\
\text { behaviors }\end{array}$ & $\begin{array}{l}\text { The ethical climate of } \\
\text { organizational rules }\end{array}$ \\
\hline \multirow{4}{*}{$\begin{array}{l}\text { Positive organizational } \\
\text { behaviors }\end{array}$} & $\begin{array}{l}\text { Pearson } \\
\text { correlation }\end{array}$ & 1 & $0.536^{\star \star}$ \\
\cline { 2 - 4 } & $\begin{array}{l}\text { Sig } \\
\text { (interquartile) }\end{array}$ & & 0.000 \\
\cline { 2 - 4 } & Number of data & 224 & 223 \\
\hline \multirow{4}{*}{$\begin{array}{l}\text { The ethical climate of } \\
\text { organizational rules }\end{array}$} & $\begin{array}{l}\text { Pearson } \\
\text { correlation }\end{array}$ & $0.536^{\star \star}$ & 1 \\
\cline { 2 - 4 } & $\begin{array}{l}\text { Sig } \\
\text { (interquartile) }\end{array}$ & 0.000 & 223 \\
\cline { 2 - 4 } & Number of data & 223 & 1 \\
\hline
\end{tabular}

\section{The evaluation of the fifth subsidiary hypothesis}

Table 10 shows the results of the test. The correlation coefficient is 0.508 for 224 data.

Therefore, the fifth subsidiary hypothesis is accepted and there is a significant relationship between the ethical climate of professional and ethical codes and regulations and positive organizational behaviors of the staff at Shahrud University of Medical Sciences. This coefficient is significant at the error level of $1 \%$ and is marked with **. 
Table 10. The results of correlation test for the fifth subsidiary hypothesis

\begin{tabular}{|l|l|l|l|}
\hline \multicolumn{2}{|c|}{} & $\begin{array}{l}\text { Positive organizational } \\
\text { behaviors }\end{array}$ & $\begin{array}{l}\text { The ethical climate } \\
\text { of professional and } \\
\text { ethical codes }\end{array}$ \\
\hline $\begin{array}{l}\text { Positive } \\
\text { organizational } \\
\text { behaviors }\end{array}$ & Pearson correlation & 1 & $0.508^{\star \star}$ \\
\cline { 2 - 4 } & Sig (interquartile) & & 0.000 \\
\hline $\begin{array}{l}\text { The ethical } \\
\text { climate of } \\
\text { professional } \\
\text { and ethical } \\
\text { codes }\end{array}$ & Number of data & 224 & 224 \\
\cline { 2 - 4 } & Sig (interquartile) & 0.000 & 1 \\
\hline
\end{tabular}

\section{The evaluation of the current status of the research components}

The one-sample t-test is used to examine the current status of the research components.

The results of this test (Table 11) showed that the status of components is desirable. The status of the components of organizational ethical climate, positive organizational behaviors, the ethical climate of caring, the instrumental ethical climate and resilience are at the medium level and the components of the ethical climate of independence, optimism, and hope is not desirable.

The two-sample t-test was used to examine the influence of the mediating variables of gender and marital status on the views of respondents.

Confidence interval for the component of organizational ethical climate: $0.00 \leq \mu-3 \leq 0.15 \rightarrow$ $3.00 \leq \mu \leq 3.15$.

Confidence interval for the component of the ethical climate of caring: $-0.26 \leq \mu-3 \leq-0.06 \rightarrow$ $2.74 \leq \mu \leq 2.94$.

Confidence interval for the component of the ethical climate of professional rules: $0.16 \leq \mu$ $3 \leq 0.40 \rightarrow 3.16 \leq \mu \leq 3.40$.

Confidence interval for the component of the ethical climate of organizational rules: $0.26 \leq \mu-3 \leq-0.04 \rightarrow 2.74 \leq \mu \leq 2.96$.

Confidence interval for the component of the instrumental ethical climate: $-0.03 \leq \mu-3 \leq 0.20$ $\rightarrow 2.97 \leq \mu \leq 3.20$.

Confidence interval for the component of the ethical climate of independence: $0.27 \leq \mu$ $3 \leq 0.54 \rightarrow 3.27 \leq \mu \leq 3.54$.

Confidence interval for the component of positive organizational behavior: $-0.05 \leq \mu-3 \leq 0.10$ $\rightarrow 2.95 \leq \mu \leq 3.10$.

Confidence interval for the component of optimism: $-0.39 \leq \mu-3 \leq-0.17 \rightarrow 2.61 \leq \mu \leq 2.83$.

Confidence interval for the component of hope: $-0.17 \leq \mu-3 \leq 0.11 \rightarrow 2.17 \leq \mu \leq 3.11$

Confidence interval for the component of self-confidence: $0.62 \leq \mu-3 \leq 0.88 \rightarrow 3.62 \leq \mu \leq 3.88$.

Confidence interval for the component of resilience: $-0.48 \leq \mu-3 \leq-0.18 \rightarrow 2.52 \leq \mu \leq 2.82$. 
Table 11. The results of one-sample t-test

\begin{tabular}{|c|c|c|c|c|c|c|c|}
\hline \multirow[t]{2}{*}{ Components } & \multirow[t]{2}{*}{$\mathbf{M}$} & \multirow[t]{2}{*}{ SD } & \multirow[t]{2}{*}{$\begin{array}{l}\mathbf{t} \\
\text { statistic }\end{array}$} & \multirow[t]{2}{*}{ Df } & \multirow[t]{2}{*}{ Sig } & \multicolumn{2}{|c|}{$\begin{array}{l}95 \% \\
\text { confidence } \\
\text { interval of } \\
\text { sample mean } \\
\text { difference }\end{array}$} \\
\hline & & & & & & $\begin{array}{l}\text { Lower } \\
\text { level }\end{array}$ & $\begin{array}{l}\text { Upper } \\
\text { level }\end{array}$ \\
\hline $\begin{array}{l}\text { Organizational ethical } \\
\text { climate }\end{array}$ & 2.98 & 0.418 & -0.873 & 223 & 0.383 & -0.08 & 0.03 \\
\hline The ethical climate of caring & 2.94 & 0.525 & -1.592 & 223 & 0.113 & -0.13 & 0.01 \\
\hline $\begin{array}{l}\text { The ethical climate of } \\
\text { professional rules }\end{array}$ & 3.10 & 0.726 & 2.063 & 223 & 0.040 & 0.00 & 0.20 \\
\hline $\begin{array}{l}\text { The ethical climate of } \\
\text { organizational rules }\end{array}$ & 3.16 & 0.660 & 3.636 & 222 & 0.000 & 0.07 & 0.25 \\
\hline $\begin{array}{l}\text { Organizational ethical } \\
\text { climate }\end{array}$ & 2.98 & 0.502 & -0.568 & 222 & 0.571 & -0.09 & 0.05 \\
\hline $\begin{array}{l}\text { The ethical climate of } \\
\text { independence }\end{array}$ & 2.71 & 0.773 & -5.577 & 222 & 0.000 & -0.39 & -0.19 \\
\hline $\begin{array}{l}\text { Positive organizational } \\
\text { behavior }\end{array}$ & 3.04 & 0.419 & 1.521 & 223 & 0.130 & -0.01 & 0.10 \\
\hline Optimism & 2.77 & 0.606 & -5.732 & 223 & 0.000 & -0.31 & -0.15 \\
\hline Hope & 2.88 & 0.671 & -2.607 & 223 & 0.010 & -0.21 & -0.03 \\
\hline Self-confidence & 3.57 & 0.832 & 10.312 & 223 & 0.000 & 0.46 & 0.68 \\
\hline Resilience & 2.95 & 0.665 & -1.088 & 223 & 0.278 & -0.14 & 0.04 \\
\hline
\end{tabular}

\section{Two-sample t-test results}

\section{The test of the role of gender in the view of respondents}

We use the two-sample t-test to measure the differences between the views of female and male respondents about the main features of organizational ethical climate and positive organizational behaviors.

The results of the test in table 12 showed that there is no significant relationship between the views of men and women with regard to the components of the instrumental ethical climate, the ethical climate of independence and self-confidence at 5\% error level and thus their views are identical. As regards the components of the organizational ethical climate, positive organizational behaviors, the ethical climate of caring, the ethical climate of professional and ethical codes, the ethical climate of organizational rules and regulations, optimism, hope, and resilience, there was a significant relationship between the views of men and women at 5\% error level and thus their views are not identical. 
Table 12. The test results of the role of gender in the view of respondents

\begin{tabular}{|c|c|c|c|c|c|c|c|c|}
\hline \multirow[b]{2}{*}{ Components } & \multirow{2}{*}{ Gender } & \multirow[b]{2}{*}{$\mathbf{M}$} & \multirow[b]{2}{*}{ SD } & \multicolumn{2}{|c|}{$\begin{array}{l}\text { Levene test for } \\
\text { the equality of } \\
\text { variances }\end{array}$} & \multicolumn{3}{|c|}{ t-test for the equality of means } \\
\hline & & & & $\begin{array}{l}\text { F } \\
\text { statistic }\end{array}$ & $\begin{array}{l}\text { Sig } \\
\text { level }\end{array}$ & $\begin{array}{l}\text { T } \\
\text { statistic }\end{array}$ & Df & $\begin{array}{l}\text { Sig } \\
\text { (interquartile) }\end{array}$ \\
\hline \multirow{2}{*}{$\begin{array}{l}\text { Organizational } \\
\text { ethical climate }\end{array}$} & Female & 2.87 & 0.409 & \multirow{2}{*}{0.487} & \multirow{2}{*}{0.486} & \multirow{2}{*}{-3.279} & \multirow{2}{*}{221} & \multirow{2}{*}{0.001} \\
\hline & Male & 3.06 & 0.410 & & & & & \\
\hline \multirow{2}{*}{$\begin{array}{l}\text { The ethical } \\
\text { climate of } \\
\text { caring }\end{array}$} & Female & 2.82 & 0.541 & \multirow{2}{*}{1.450} & \multirow{2}{*}{0.230} & \multirow{2}{*}{-3.149} & \multirow{2}{*}{221} & \multirow{2}{*}{0.002} \\
\hline & Male & 3.04 & 0.496 & & & & & \\
\hline \multirow{2}{*}{$\begin{array}{l}\text { The ethical } \\
\text { climate of } \\
\text { professional } \\
\text { rules }\end{array}$} & Female & 2.93 & 0.759 & \multirow[b]{2}{*}{1.720} & \multirow[b]{2}{*}{0.191} & \multirow[b]{2}{*}{-3.041} & \multirow[b]{2}{*}{221} & \multirow[b]{2}{*}{0.003} \\
\hline & Male & 3.23 & 0.678 & & & & & \\
\hline \multirow{2}{*}{$\begin{array}{l}\text { The ethical } \\
\text { climate of } \\
\text { organizational } \\
\text { rules }\end{array}$} & Female & 3.02 & 0.699 & \multirow[b]{2}{*}{0.777} & \multirow[b]{2}{*}{0.379} & \multirow[b]{2}{*}{-2.887} & \multirow[b]{2}{*}{220} & \multirow[b]{2}{*}{0.004} \\
\hline & Male & 3.27 & 0.610 & & & & & \\
\hline \multirow{2}{*}{$\begin{array}{l}\text { Instrumental } \\
\text { ethical climate }\end{array}$} & Female & 2.94 & 0.534 & \multirow{2}{*}{1.334} & \multirow{2}{*}{0.249} & -1080 & 20 & 0278 \\
\hline & Male & 3.01 & 0.479 & & & 1.007 & 220 & 0.210 \\
\hline The ethical & Female & 2.64 & 0.769 & & & & & \\
\hline $\begin{array}{l}\text { climate of } \\
\text { independence }\end{array}$ & Male & 2.76 & 0.778 & 0.013 & 0.908 & -1.206 & 220 & 0.229 \\
\hline Positive & Female & 2.94 & 0.390 & & & & & \\
\hline $\begin{array}{l}\text { organizational } \\
\text { behaviors }\end{array}$ & Male & 3.12 & 0.426 & 0.102 & 0.749 & -3.353 & 221 & 0.001 \\
\hline & Female & 2.63 & 0.543 & & 0226 & -2.985 & 221 & 0003 \\
\hline Uptimism & Male & 2.87 & 0.635 & $1.4 / 1$ & $0 . \angle \angle 0$ & -2.903 & 221 & 0.003 \\
\hline Hope & Female & 2.78 & 0.623 & 1168 & 0281 & -2054 & 221 & 0.041 \\
\hline Поре & Male & 2.96 & 0.698 & 1.108 & 0.281 & -2.004 & 221 & 0.041 \\
\hline Self- & Female & 3.54 & 0.851 & 0.014 & 0.908 & -0.502 & 221 & 0.616 \\
\hline confidence & Male & 3.60 & 0.822 & & & & & \\
\hline Resilience & Female & 2.81 & 0.555 & 4.440 & 0.036 & -2899 & 220993 & 0.004 \\
\hline Кеsinente & Male & 3.06 & 0.726 & 4.440 & & & & \\
\hline
\end{tabular}

The evaluation of the role of marital status in the view of respondents

The results of the test showed that there is no significant relationship between the views of married and single respondents with regard to the components of the instrumental ethical climate, organizational ethical climate, positive organizational behaviors, the ethical climate of caring, the ethical climate of professional and ethical codes, the ethical climate of organizational rules and regulations, optimism, hope, and resilience, the ethical climate of 
independence and self-confidence at 5\% error level and thus their views are identical in this regard.

\section{The results of multiple comparisons of population means (ANOVA)}

\section{The test of the role of age in the view of respondents}

The results of table 13 showed that the views are identical in the components of the organizational ethical climate, positive organizational behaviors, the ethical climate of caring, the ethical climate of professional and ethical codes, the ethical climate of organizational rules and regulations, optimism, hope, and resilience. However, the views differ in the components of instrumental ethical climate and the ethical climate of independence.

Table 13. The results of the test of the role of age in respondents' views

\begin{tabular}{|l|l|l|l|l|l|l|}
\hline $\begin{array}{l}\text { The ethical } \\
\text { climate of } \\
\text { independence }\end{array}$ & $\begin{array}{l}\text { Instrumental } \\
\text { ethical } \\
\text { climate }\end{array}$ & $\begin{array}{l}\text { The ethical } \\
\text { climate of } \\
\text { organizational } \\
\text { rules }\end{array}$ & $\begin{array}{l}\text { The ethical } \\
\text { climate of } \\
\text { professional } \\
\text { rules }\end{array}$ & $\begin{array}{l}\text { The } \\
\text { ethical } \\
\text { climate of } \\
\text { caring }\end{array}$ & $\begin{array}{l}\text { Organizational } \\
\text { ethical climate }\end{array}$ & Component \\
\hline 2.912 & 3.503 & 1.943 & 1.520 & 0.475 & 2.411 & F statistic \\
\hline 0.035 & 0.016 & 0.124 & 0.210 & 0.700 & 0.068 & Sig value \\
\hline Resilience & $\begin{array}{l}\text { Self- } \\
\text { confidence }\end{array}$ & Hope & Optimism & $\begin{array}{l}\text { Positive } \\
\text { organizational } \\
\text { behaviors }\end{array}$ & Component \\
\hline 0.827 & 0.931 & 2.219 & 0.324 & 0.460 & F statistic \\
\hline 0.480 & 0.427 & 0.087 & 0.808 & 0.711 & Sig value \\
\hline
\end{tabular}

To determine which means are different with regard to the components of instrumental ethical climate and the ethical climate of independence, we use a post-hoc test. One such test is Tukey which is going to be discussed in what follows.

\section{The instrumental ethical climate}

In Table 14, the Tukey test results are provided. In the column dealing with the difference of means, the significant differences are marked with *. As can be seen, according to Tukey test, there is a significant difference between the mean of 41 to 50 age group and the mean of the age group above 50 years ( $\mathrm{Sig}$ value is less than $5 \%$ ).

Table 14. Tukey test results for the component of instrumental ethical climate

\begin{tabular}{|l|l|l|l|l|}
\hline \multirow{5}{*}{ Dependent variable } & \multirow{2}{*}{ Age $(\mathrm{I})$} & Age $(\mathrm{J})$ & SD $(\mathrm{I}-\mathrm{J})$ & \multirow{2}{*}{ Sig. } \\
\hline \multirow{4}{*}{ Instrumental ethical climate } & \multirow{3}{*}{$40-30$ years } & $40-31$ years & -0.023 & 0.994 \\
\cline { 3 - 5 } & & $50-41$ years & 0.161 & 0.362 \\
\cline { 3 - 5 } & \multirow{3}{*}{$40-31$ years } & Above 50 & -0.214 & 0.349 \\
\cline { 3 - 5 } & & $20-30$ years & 0.023 & 0.994 \\
\cline { 3 - 5 } & \multirow{3}{*}{$50-41$ years } & Above 50 & -0.191 & 0.363 \\
\cline { 3 - 5 } & & $20-30$ years & -0.161 & 0.362 \\
\cline { 3 - 5 } & & $40-31$ years & -0.184 & 0.112 \\
\cline { 3 - 5 } & & Above 50 & $-0.375^{\star}$ & 0.014 \\
\hline
\end{tabular}




\begin{tabular}{|l|l|l|l|l|}
\hline \multirow{3}{*}{ Above 50 } & $20-30$ years & 0.214 & 0.349 \\
\cline { 3 - 5 } & & $40-31$ years & 0.191 & 0.363 \\
\cline { 3 - 5 } & & $50-41$ years & $0.375^{\star}$ & 0.014 \\
\hline
\end{tabular}

\section{The ethical climate of independence}

According to Tukey test, there is a significance difference between the means of different age groups ( $\mathrm{Sig}$ value is above $5 \%$ )

\section{The test of the role of educational level in respondents' views}

The results of table 15 showed that the views are identical in the components of the ethical climate of caring, the ethical climate of organizational rules and regulations, hope, and selfconfidence. However, the views differ in the components of instrumental ethical climate and the ethical climate of independence, the ethical climate of the organization, positive organizational behaviors, the ethical climate of professional and ethical codes, optimism, and resilience.

Table 15. The results of the role of education in respondents' views

\begin{tabular}{|l|l|l|l|l|l|l|}
\hline $\begin{array}{l}\text { The ethical } \\
\text { climate of } \\
\text { independence }\end{array}$ & $\begin{array}{l}\text { Instrumental } \\
\text { ethical } \\
\text { climate }\end{array}$ & $\begin{array}{l}\text { The ethical } \\
\text { climate of } \\
\text { organizational } \\
\text { rules }\end{array}$ & $\begin{array}{l}\text { The ethical } \\
\text { climate of } \\
\text { professional } \\
\text { rules }\end{array}$ & $\begin{array}{l}\text { The } \\
\text { ethical } \\
\text { climate of } \\
\text { caring }\end{array}$ & $\begin{array}{l}\text { Organizational } \\
\text { ethical climate }\end{array}$ & Component \\
\hline 6.098 & 4.296 & 1.239 & 2.914 & 1.342 & 4.701 & F statistic \\
\hline 0.000 & 0.002 & 0.295 & 0.022 & 0.255 & 0.001 & Sig value \\
\hline Resilience & $\begin{array}{l}\text { Self- } \\
\text { confidence }\end{array}$ & Hope & Optimism & $\begin{array}{l}\text { Positive } \\
\text { organizational } \\
\text { behaviors }\end{array}$ & Component \\
\hline 4.291 & 1.815 & 2.048 & 4.656 & 3.216 & F statistic \\
\hline 0.002 & 0.127 & 0.089 & 0.001 & 0.014 & Sig value \\
\hline
\end{tabular}

We use Tukey test to determine which means are different with regard to the components of organizational ethical climate, positive organizational behaviors, the ethical climate of professional and ethical codes, instrumental ethical climate, the ethical climate of independence, optimism and resilience. In what follows, these components will be discussed.

\section{The ethical climate of the organization}

In Table 16, the Tukey test results are provided. As can be seen, according to Tukey test, there is a significant difference between the mean of the group with high school completion degrees and the mean of the group holding BAs. There is also a significant difference between the mean of the group with high school completion degrees and the mean of the group holding Mas. This is also true of the mean of the group with high school diplomas and that of the group holding $\mathrm{PhDs}$ (Sig value is less than 5\%). 
Table 16. Tukey test results for the component of organizational ethical climate

\begin{tabular}{|c|c|c|c|c|}
\hline Dependent variable & Education level (I) & Education level (J) & $\begin{array}{l}\text { SD } \quad(\mathrm{I}- \\
\mathrm{J})\end{array}$ & Sig. \\
\hline \multirow{20}{*}{$\begin{array}{l}\text { Organizational } \\
\text { climate }\end{array}$} & \multirow{4}{*}{$\begin{array}{l}\text { High } \\
\text { Diploma }\end{array}$} & Associate's Degree & 0.218 & 0.275 \\
\hline & & BA & $0.376^{*}$ & 0.001 \\
\hline & & MA & $0.308^{*}$ & 0.033 \\
\hline & & $\mathrm{PhD}$ & $0.416^{*}$ & 0.007 \\
\hline & \multirow{4}{*}{ Associate's Degree } & $\begin{array}{ll}\text { High } & \text { School } \\
\text { Diploma } & \\
\end{array}$ & -0.218 & 0.275 \\
\hline & & BA & 0.157 & 0.269 \\
\hline & & MA & 0.090 & 0.861 \\
\hline & & $\mathrm{PhD}$ & 0.197 & 0.376 \\
\hline & \multirow{4}{*}{ BA } & $\begin{array}{ll}\text { High } & \text { School } \\
\text { Diploma } & \\
\end{array}$ & $-0.376^{*}$ & 0.001 \\
\hline & & Associate's Degree & -0.157 & 0.269 \\
\hline & & MA & -0.067 & 0.893 \\
\hline & & $\mathrm{PhD}$ & 0.040 & 0.994 \\
\hline & \multirow{4}{*}{ MA } & $\begin{array}{ll}\text { High } & \text { School } \\
\text { Diploma } & \\
\end{array}$ & $-0.308^{*}$ & 0.033 \\
\hline & & Associate's Degree & -0.090 & 0.861 \\
\hline & & $\mathrm{BA}$ & 0.067 & 0.893 \\
\hline & & $\mathrm{PhD}$ & 0.107 & 0.851 \\
\hline & \multirow{4}{*}{$\mathrm{PhD}$} & $\begin{array}{ll}\text { High } & \text { School } \\
\text { Diploma } & \\
\end{array}$ & $-0.416^{*}$ & 0.007 \\
\hline & & Associate's Degree & -0.197 & 0.376 \\
\hline & & BA & -0.040 & 0.994 \\
\hline & & MA & -0.107 & 0.851 \\
\hline
\end{tabular}

\section{The ethical climate of professional rules}

According to Tukey test, there is a significant difference between the mean of the group with high school diplomas and the mean of the group with bachelor's degrees (The significance value is less than $5 \%$ ).

\section{The instrumental ethical climate}

According to Tukey test, there is a significant difference between the mean of the group with high school diplomas and the mean of the group with Bachelor's Degrees and also the mean of the group with high school diplomas and the mean of the group with $\mathrm{PhDs}$ (The significance value is less than $5 \%$ ).

\section{The ethical climate of independence}

According to Tukey test, there is a significant difference between the mean of the group with high school diplomas and the mean of the group with bachelor's degrees and the mean of the group with high school diplomas and the mean of the group with Master's Degrees, and also the mean of the group with high school diplomas and that of the group with $\mathrm{PhDs}$ (The significance value is less than $5 \%$ ). 


\section{Positive organizational behaviors}

According to Tukey test, there is a significant difference between the mean of the group with high school diplomas and the mean of the group with bachelor's degrees and also the mean of the group with high school diplomas and the mean of the group with Master's Degrees (The significance value is less than $5 \%$ ).

\section{Optimism}

According to Tukey test, there is a significant difference between the mean of the group with $\mathrm{PhDs}$ and the mean of the group with high school diplomas, the mean of the group with PhDs and the mean of the group with Associate's Degrees, the mean of the group with PhDs and the mean of the group with BAs, and also the mean of the educational group holding a $\mathrm{PhD}$ and those with an MA (The significance value is less than 5\%).

\section{Resilience}

According to Tukey test, there is a significant difference between the mean of the group with high school diplomas and the mean of the group with Associate's Degrees, the mean of the group with high school diplomas and the mean of the group with Bachelor's Degrees, the mean of the group with high school diploma and the mean of the group with Mas, and the mean of the educational group holding a $\mathrm{PhD}$ and those with a high school completion degree (The significance value is less than 5\%).

\section{The evaluation of the effect of the years of service in the view of respondents}

The results of table 17 showed that the views are identical in the components of positive organizational behaviors, instrumental ethical climate, optimism, hope, and self-confidence.

However, the views differ in the components of the ethical climate of independence, the ethical climate of caring, the ethical climate of the organization, the ethical climate of organizational rules and regulations, the ethical climate of professional and ethical codes, and resilience.

Table 17. The test results concerning years of service in respondents' views

\begin{tabular}{|l|l|l|l|l|l|l|}
\hline $\begin{array}{l}\text { The ethical } \\
\text { climate of } \\
\text { independence }\end{array}$ & $\begin{array}{l}\text { Instrumental } \\
\text { ethical } \\
\text { climate }\end{array}$ & $\begin{array}{l}\text { The ethical } \\
\text { climate of } \\
\text { organizational } \\
\text { rules }\end{array}$ & $\begin{array}{l}\text { The ethical } \\
\text { climate of } \\
\text { professional } \\
\text { rules }\end{array}$ & $\begin{array}{l}\text { The } \\
\text { ethical } \\
\text { climate of } \\
\text { caring }\end{array}$ & $\begin{array}{l}\text { Organizational } \\
\text { ethical climate }\end{array}$ & component \\
\hline 2.827 & 0.711 & 2.875 & 2.524 & 3.694 & 3.763 & F statistic \\
\hline 0.026 & 0.586 & 0.024 & 0.042 & 0.006 & 0.006 & Sig value \\
\hline Resilience & $\begin{array}{l}\text { Self- } \\
\text { confidence }\end{array}$ & Hope & Optimism & $\begin{array}{l}\text { Positive } \\
\text { organizational } \\
\text { behaviors }\end{array}$ & component \\
\hline 2.564 & 1.174 & 0.473 & 1.537 & 1.277 & F statistic \\
\hline 0.039 & 0.323 & 0.755 & 0.192 & 0.280 & Sig value \\
\hline
\end{tabular}

We use Tukey test to determine which means are different with regard to the components of the organizational ethical climate, the ethical climate of caring, the ethical climate of professional and ethical codes, the ethical climate of organizational rules and regulations, the ethical climate of independence, and resilience. In what follows, these components will be discussed. 


\section{The ethical climate of the organization}

In Table 18, the Tukey test results are provided. As can be seen, according to Tukey test, there is a significant difference between the mean of the group with 5 to 10 years of service and the mean of the group with 16 to 20 years of service.

There is also a significant difference between the group with 11 to 15 years of service and the one with 16 to 20 years of service (Sig value is less than 5\%).

Table 18. The results of Tukey test for the component of organizational ethical climate

\begin{tabular}{|c|c|c|c|c|}
\hline Dependent variable & $\begin{array}{l}\text { Years of service } \\
\text { (I) }\end{array}$ & $\begin{array}{l}\text { Years of service } \\
(\mathrm{J})\end{array}$ & $\mathrm{SD}(\mathrm{I}-\mathrm{J})$ & Sig. \\
\hline \multirow{20}{*}{$\begin{array}{l}\text { Organizational } \\
\text { climate }\end{array}$} & \multirow{4}{*}{ Less than 5 years } & $5-10$ years & -0.067 & 0.903 \\
\hline & & $11-15$ years & -0.169 & 0.286 \\
\hline & & $20-16$ years & 0.158 & 0.347 \\
\hline & & $\begin{array}{l}\text { More than } 20 \\
\text { years }\end{array}$ & -0.075 & 0.958 \\
\hline & \multirow{4}{*}{$5-10$ years } & Less than 5 years & 0.067 & 0.903 \\
\hline & & $11-15$ years & -0.102 & 0.707 \\
\hline & & $20-16$ years & $0.225^{*}$ & 0.039 \\
\hline & & $\begin{array}{l}\begin{array}{l}\text { More than } 20 \\
\text { years }\end{array} \\
\end{array}$ & -0.008 & 1.000 \\
\hline & \multirow{4}{*}{$11-15$ years } & Less than 5 years & 0.169 & 0.286 \\
\hline & & $5-10$ years & 0.102 & 0.707 \\
\hline & & $20-16$ years & $0.326^{*}$ & 0.003 \\
\hline & & $\begin{array}{l}\text { More than } 20 \\
\text { years }\end{array}$ & 0.094 & 0.916 \\
\hline & \multirow{4}{*}{$20-16$ years } & Less than 5 years & -0.158 & 0.347 \\
\hline & & $5-10$ years & $-0.225^{*}$ & 0.039 \\
\hline & & $11-15$ years & $-0.326^{*}$ & 0.003 \\
\hline & & $\begin{array}{l}\text { More than } 20 \\
\text { years }\end{array}$ & -0.233 & 0.220 \\
\hline & \multirow{4}{*}{$\begin{array}{l}\text { More than } 20 \\
\text { years }\end{array}$} & Less than 5 years & 0.075 & 0.958 \\
\hline & & $5-10$ years & 0.008 & 1.000 \\
\hline & & $11-15$ years & -0.094 & 0.916 \\
\hline & & $20-16$ years & 0.233 & 0.220 \\
\hline
\end{tabular}

\section{The ethical component of caring}

Based on the results of Tukey test, there is a significant difference between the mean of the group with 11 to 15 years of service and the mean of the group with 16 to 20 years of service (i.e. Sig value is less than $5 \%$ ).

\section{The ethical climate of profession and ethical codes}

Based on the results of Tukey test, there is a significant difference between the mean of the group with 11 to 15 years of service and the mean of the group with 16 to 20 years of service (i.e. Sig value is less than $5 \%$ ).

\section{The ethical climate of organizational rules and regulations}

Based on the results of Tukey test, there is a significant difference between the mean of the group with 11 to 15 years of service and the mean of the group with 16 to 20 years of service (i.e. Sig value is less than $5 \%$ ). 


\section{The ethical climate of independence}

Based on the results of Tukey test, there is no significant difference between the mean of the groups with different years of service (i.e. Sig value is larger than 5\%).

\section{Resilience}

Based on the results of Tukey test, there is a significant difference between the mean of the group with 5 to 10 years of service and the mean of the group with 16 to 20 years of service (i.e. Sig value is less than $5 \%$ ).

\section{The evaluation of the role of employment status in respondents' views (Multiple comparisons of population means: ANOVA)}

The results of table 19 showed that the views of different groups with various employment types are identical in all components of positive organizational behaviors, instrumental ethical climate, optimism, hope, self-confidence, the ethical climate of independence, the ethical climate of caring, the ethical climate of the organization, the ethical climate of organizational rules and regulations, the ethical climate of professional and ethical codes, and resilience.

Table 19. The evaluation of the role of employment status in respondents' views

\begin{tabular}{|l|l|l|l|l|l|l|}
\hline $\begin{array}{l}\text { The ethical } \\
\text { climate of } \\
\text { independence }\end{array}$ & $\begin{array}{l}\text { Instrumental } \\
\text { ethical } \\
\text { climate }\end{array}$ & $\begin{array}{l}\text { The ethical } \\
\text { climate of } \\
\text { organizational } \\
\text { rules }\end{array}$ & $\begin{array}{l}\text { The ethical } \\
\text { climate of } \\
\text { professional } \\
\text { rules }\end{array}$ & $\begin{array}{l}\text { The } \\
\text { ethical } \\
\text { climate of } \\
\text { caring }\end{array}$ & $\begin{array}{l}\text { Organizational } \\
\text { ethical climate }\end{array}$ & component \\
\hline 0.864 & 0.980 & 1.798 & 0.727 & 2.587 & 0.891 & F statistic \\
\hline 0.460 & 0.403 & 0.149 & 0.537 & 0.054 & 0.447 & Sig value \\
\hline Resilience & $\begin{array}{l}\text { Self- } \\
\text { confidence }\end{array}$ & Hope & Optimism & $\begin{array}{l}\text { Positive } \\
\text { organizational } \\
\text { behaviors }\end{array}$ & component \\
\hline 0.449 & 0.107 & 0.666 & 1.824 & 0.828 & F statistic \\
\hline 0.718 & 0.956 & 0.574 & 0.144 & 0.480 & Sig value \\
\hline
\end{tabular}

\section{Conclusions}

The results show that the administrators of Shahrud University of Medical Sciences can manage the ethical climate of the organization to affect the behaviors of the staff at the organization and increase the positive and ethical behaviors of the organization. It is imperative that the administrators of Shahrud University of Medical Sciences know that expecting ethical behaviors and positive organizational behaviors to emerge among the staff is completely beneficial so long as they act accordingly. The behaviors governing the organization are fully mutual which means that undesirable behavior from one side cannot be followed by the positive behavior of the other side. Then, if organizations are willing to improve their behavioral environment, they should be committed to act in an ethical and humane manner before advising their staff to act accordingly. As an organization expects to observe positive organizational behavior among the employees more frequently, it must promote the commitment regarding ethical behaviors towards the employees and the entire organization.

The way employees behave is a reflection on the managers and, if this is the case, any change in this reflection involves changing the initial behaviors. The theory of ethical climate points to the fact that it is possible to make practical efforts to manage the ethical climate of organizations instead of making laws and regulations and resorting to the disciplinary, unilateral, and managerial control along with reinforcements and restrictions (which are often counterproductive). 
In this way, some kind of conscious commitment and responsibility will emerge for the staff and managers and negative organizational behaviors will be replaced with positive alternatives.

\section{Final analysis model}

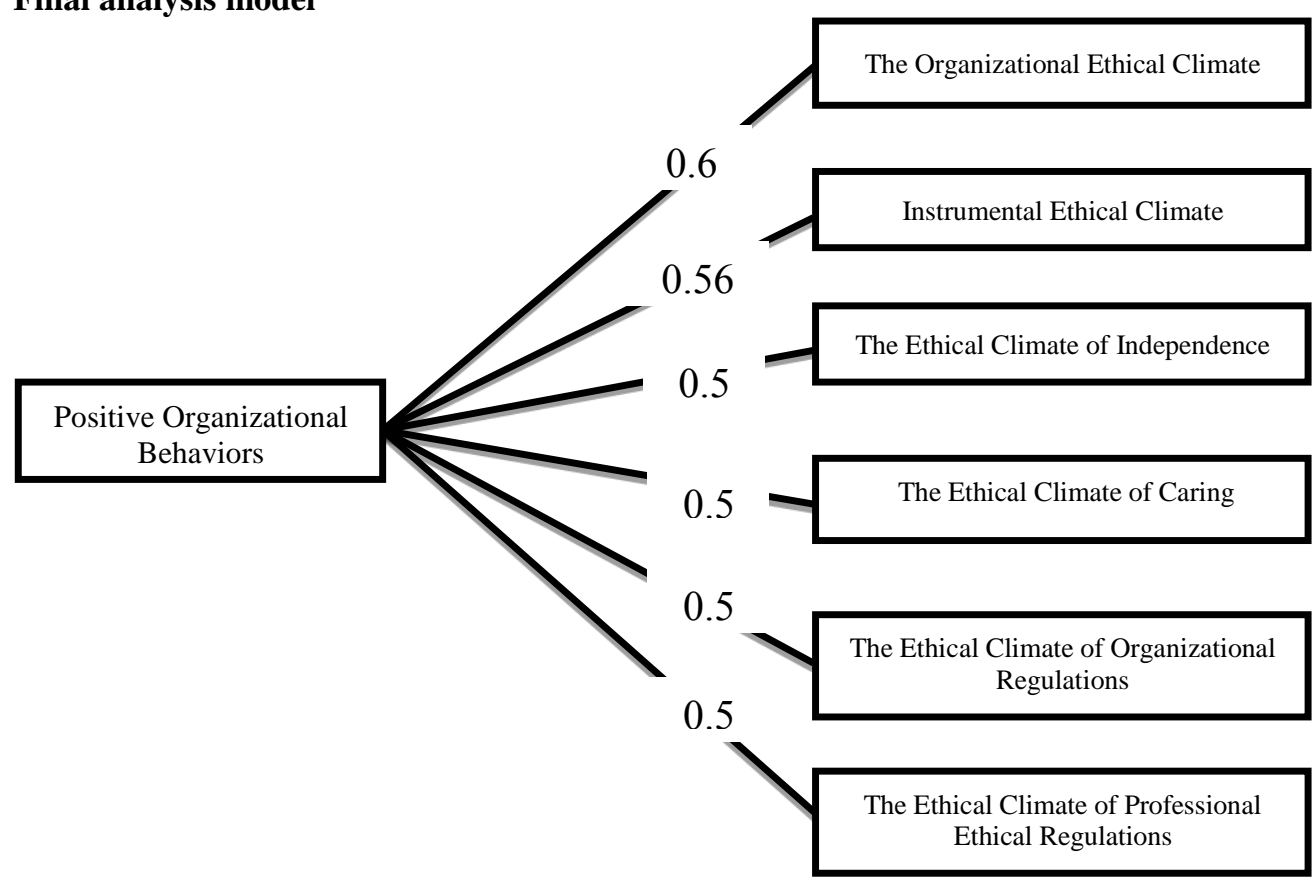

Fig. 3. The final analysis models

\section{REFERENCES}

1. Bahcecik, N., Ozturk. (2003). The Hospital ethical climate survey in turkey, JOANS Health law, Ethics Regul. (5), pp. 94-98.

2. Cullen, J. B., Parboteeah, K. P., Victor, B. (2003). "The effects of ethical climates on organizational commitment: A two-study analysis", Journal of Business Ethics, No. 46, pp. 127-141.

3. Fogel, KM. (2007). The relationship of moral distress, ethical climate, and intent to turnover among critical care nurse, Ph. D Dissertation in Philosophy, University of Chicago.

4. Luthans, Fred, Youssef, Carolyn (2007a). "Emerging Positive Organizational Behavior", Journal of Management, Vol. 33, No. 3, pp. 321-349.

5. Luthans Fred, Luthans Kyle W. \& Luthans Bert C. (2004). Positive Psychological Capital: Beyond human and social capital, Journal of Business Horizons. 47:(1), pp. 45-50.

6. Luthans, F., \& Youssef, C. M. (2004). Human, social, and now positive psychological capital management: Investing in people for competitive advantage, Organizational Dynamics, 33:(2), pp. 143-160.

7. Luthans, F., Avey, J. B., \& Patera, J. L. (2008). Experimental analysis of a Webbased intervention to develop positive psychological capital, Journal of Academy of Management Learning and Education, (7), pp. 209-221. 
8. Schluter, J., Winch, S., Holzhauser, K., Henderson, A. (2008). Nurses' moral sensitivity and hospital ethical climate, Nursing Ethics, 15(3), pp. 305-321.

9. Schluter, J., Winch, S., Holzhauser, K., Henderson, A. (2008). Nurses' moral sensitivity and hospital ethical climate, Nursing Ethics, 15(3), pp. 305-321.

10. Simar Asl, Nastaran; Fayazi, Marjan; Gholipoor, Ariyan (2010). An explanation of the consequences of positive psychological factors in an organization, The Quarterly Journal of Management Sciences of Iran, No. 17, pp. 1-24.

11. Wimbush, J. C. and J. M. Shepard (1994). "Toward on understanding of ethical climate: Its relationship to ethical behavior and supervisory influence", Journal of Business Ethics, No. 13, pp. 637-647.

\section{Article history:}

Received 17 November 2017

Accepted 15 May 2018 